The International Review of the Red Cross is the official publication of the International Committee of the Red Cross. It was first published in 1869 under the title "Bulletin international des Sociétés de secours aux militaires blessés", and then "Bulletin international des Sociétés de la Croix-Rouge".

The International Review of the Red Cross is a forum for reflection and comment and serves as a reference work on the mission and guiding principles of the International Red Cross and Red Crescent Movement. It is also a specialized journal in the field of international humanitarian law and other aspects of humanitarian endeavour.

As a chronicle of the international activities of the Movement and a record of events, the International Review of the Red Cross is a constant source of information and maintains a link between the components of the International Red Cross and Red Crescent Movement.

The International Review of the Red Cross is published every two months, in four main editions:

French: REVUE INTERNATIONALE DE LA CROIX-ROUGE (since October 1869)

English: INTERNATIONAL REVIEW OF THE RED CROSS (since April 1961)

Spanish: REVISTA INTERNACIONAL DE LA CRUZ ROJA (since January 1976)

Arabic: المجلة الدولية لنصئيب الأحمر

(since May-June 1988)

Selected articles from the main editions have also been published in German under the title Auszüge since January 1950

EDITOR: Jacques Meurant, D. Pol. Sci.

ADDRESS: International Review of the Red Cross

19, avenue de la Paix

1202 - Geneva, Switzerland

SUBSCRIPTIONS: one year, 30 Swiss francs or US\$ 18

single copy, 5 Swiss francs.

Postal cheque account No. 12 - 1767-1 Geneva

Bank account No. 129.986, Swiss Bank Corporation, Geneva

The International Committee of the Red Cross (ICRC), together with the League of the Red Cross and Red Crescent Societies and the 148 recognized National Red Cross and Red Crescent Societies, is one of the three components of the International Red Cross and Red Crescent Movement.

An independent humanitarian institution, the ICRC is the founding body of the Red Cross. As a neutral intermediary in case of armed conflict or disturbances, it endeavours on its own initiative or on the basis of the Geneva Conventions to protect and assist the victims of international and civil wars and of internal troubles and tensions, thereby contributing to peace in the world. 


\section{INTERNATIONAL REVIEW}

International humanitarian law and non-international armed conflicts

Rules of international humanitarian law governing the conduct of hostilities in non-international armed conflicts

\section{International humanitarian law and the protection of children}

Captured child combatants 